\title{
Are homicides and robberies associated with mortality due to COVID-19? Lessons from Urban Mexico
}

\author{
Claudia Masferrer ${ }^{1, *}$ and Oscar Rodríguez, Chávez ${ }^{2}$
}

\begin{abstract}
Studies on the symbiosis of crime and COVID-19 have analyzed governmentmandated lockdown effects. However, it is unknown to what extent previous crime rates determined a larger and more mortal spread of the pandemic. We study how homicides and robberies in the pre-pandemic year of 2019 are associated with 2020 mortality rates due to COVID-19 in urban municipalities in Mexico. Considering sex differentials in health, exposure to the virus and experiences of violence, we study whether gender differences in mortality exist in 2020. Using publicly available data on deaths due to COVID-19 provided by the Mexican Secretariat of Health, along with a series of indicators to characterize local pre-pandemic conditions of urban municipalities, we estimate a series of ordinary least squares (OLS) regression models on age-standardized crude death rates (ASCDR) by sex. Findings show that homicides - a proxy for criminal violence that might encourage people to stay home-show significant negative associations with mortality rates. Comparatively, robberies - a proxy of local violence and safety-were positively associated with mortality rates for both sexes. Sex differences in the determinants of ASCDR are discussed.
\end{abstract}

Keywords: COVID-19; criminal violence; social determinants of mortality; gender differences in mortality; urban areas; Mexico

\footnotetext{
${ }^{1}$ Centro de Estudios Demográficos, Urbanos y Ambientales, El Colegio de México, Mexico City, Mexico

${ }^{2}$ Departamento de Estudios de Población, El Colegio de la Frontera Norte, Juárez, Chihuahua, Mexico ${ }^{*}$ Correspondence to: Claudia Masferrer, cmasferrer@ colmex.mx
} 


\section{Introduction}

The link between COVID-19 and violence has been studied by analyzing to what extent physical distancing measures, lockdowns, and stay-at-home mandates impact the incidence of different types of crime, such as domestic and child abuse, crime in public spaces and crime by gangs and organized groups. For example, research on cities in the United States, Canada and Australia has shown that while lockdown measures led to reductions in thefts, robberies and crime in public spaces; and to increases in domestic violence and other types of crimes committed in private spaces, as well as in phone extortion and cybercrime; these measures had no effects on homicides and kidnapping by organized crime groups (Abrams, 2021; Boman and Gallupe, 2020; Hodgkinson and Andresen, 2020; Mohler et al., 2020; Payne and Morgan, 2020). Such findings are in line with research for Mexico City: while conventional crime declined, organized crime remained steady (Balmori de la Miyar et al., 2021). Although many of these studies took prior crime into account in their analyses of crime levels after the onset of the pandemic, it is unclear to what extent adverse social contexts characterized by high levels of violence and a lack of safety are associated with a wider spread of and higher mortality from SARS-CoV-2.

In this paper, we investigate the complex association between COVID-19 and crime and violence by considering whether crime and violence rates in communities prior to the COVID-19 pandemic were associated with 2020 mortality rates due to COVID-19 in urban Mexico. Although our analysis does not allow us to make causal claims, it sheds light on how past vulnerabilities and socioeconomic conditions in general shaped the impact of the pandemic. We also consider whether these associations vary for men and women, taking into account (1) that mortality due to COVID-19 differs by sex, and (2) that men and women experience crime differently. Understanding the association between violence and crime rates in the pre-pandemic year of 2019 and mortality rates attributed to COVID-19 in 2020 provides insights into crime as a social determinant of the severity of the pandemic. Mexico is an interesting case study due to its high levels of socioeconomic inequality, including disparities related to development levels, access to health services, demographic characteristics, gender and other indicators (El Colegio de México, 2018). Moreover, violence has not ceased over the last 15 years since President Calderón declared the so-called War on Drugs in December 2006: confrontations between cartels have increased deaths, and violence has dispersed widely from northern and western Mexico to the rest of the country (Arteaga-Botello et al., 2019). Some regions have been more affected than others, and even during the pandemic, there have been disputes over the cartel control of territories in terms of production, transportation, distribution and sales of illicit drugs (Nájar, 2020a). 


\section{Background}

\subsection{Neighborhood effects on health}

The prevalence of COVID-19, similar to other diseases, is associated with social processes rooted in historical systems of income inequality, social stratification and residential segregation. Many of these processes occur locally, in the neighborhoods where people live and work, and affect exposure to the virus due to overcrowding, population density and on-the-job risk exposure. The likelihood of being infected with COVID-19, and the severity and fatality of such an infection, depend on an individual's stressors, underlying chronic conditions/comorbidities and access to quality care (DiezRoux, 2020). According to the theory of syndemics, the consequences of a disease can interact with social, environmental and economic factors, which can in turn, worsen the effects of the disease and exacerbate health inequities (Tsai et al., 2017). Disparities in local conditions may amplify inequalities in health behaviors, as the pandemic has created a larger health burden in already vulnerable places, affecting people from lower socioeconomic groups in urban areas the most, as evidenced in Great Britain (Kulu and Dorey, 2021). For example, perceived neighborhood conditions have shaped the impacts of COVID-19 on mental health and physical activity among adults in the United States (Yang and Xiang, 2021) and among children in Canada (Mitra et al., 2020) by adding health burdens to residents of disadvantaged neighborhoods. Neighborhoods with low poverty and a lack of negative conditions (such as low levels of crime, violence or traffic) tend to have health-promoting conditions prior to the pandemic that resulted in their residents having better mental health and more physical activity during the pandemic (Yang and Xiang, 2021). Moreover, positive neighborhood conditions can protect against other health problems: for example, neighborhood social cohesion is associated with successfully quitting smoking in Mexico (Lozano et al., 2016).

Physical distancing - commonly imposed by public health officials as a means of preventing the spread of COVID-19 (WHO, 2021) - is almost impossible among the urban poor (Wasdani and Prasad, 2020). The neighborhood exerts shortterm influences on behaviors, attitudes and health care utilization, and has longterm weathering effects that accumulate over time, making populations of poorer communities more vulnerable to a given disease (Ellen et al., 2001). In urban Mexico, for example, local conditions-such as the retail food environment-have been associated with the prevalence of diabetes (Perez-Ferrer et al., 2020), exposing people to further health risks. Mexico has long had severe public health problems due to the prevalence of obesity and diabetes (Moreno-Altamirano et al., 2014). The prevalence of obesity continues to increase, regardless of socioeconomic level, region or locality (Barquera et al., 2020). Moreover, obesity and undernutrition coexist in Mexico (Rivera et al., 2014). Type 2 diabetes impacts the Mexican 
adult population aged 45 and older, particularly men, and homicides ${ }^{1}$ due to criminal violence impact youth aged 15 to 44 . These two public health challenges of high rates of diabetes and homicide are mainly responsible for the stagnation of life expectancy in Mexico since 2000 (Canudas-Romo et al., 2015). Obesity and diabetes are well-known comorbidities associated with COVID-19 (DenovaGutiérrez et al., 2020; Ejaz et al., 2020), and they are major risk factors for death in patients with COVID-19, particularly for older men in Mexico (Bello-Chavolla et al., 2020; Peña et al., 2021).

Although adverse socioeconomic circumstances are consistently associated with higher mortality (Nandi and Kawachi, 2011) and low birth weight (Morenoff, 2003), these associations vary and are moderated by individual-level characteristics. Only a few studies have analyzed the neighborhood effects on the incidence of COVID-19, including a study on the incidence of COVID-19 in New York City (Sy et al., 2021); a study on predictors of COVID-19 cases and deaths at the county level in the United States that focused on the vulnerability of Latino populations (Rodriguez-Diaz et al., 2020); and a study on how socioeconomic status was associated with the incidence of and mortality from COVID-19 in Santiago, Chile (Mena et al., 2021). Overall, these analyses found that the neighborhood demographic profile and socioeconomic status matter, i.e., that higher rates of employment in frontline occupations, higher rates of heart disease and less physical distancing were positively associated with COVID-19 cases at the county level. However, there are reasons to believe this might be different in Mexico, as at the beginning of the pandemic, the incidence of COVID-19 was concentrated in large metropolitan areas with low levels of poverty (CONEVAL, 2020). Although COVID-19 spread throughout the country, poor rural and urban municipalities in Mexico sought to prevent the spread of the virus by implementing measures aimed at promoting physical distancing and restricting the entry of tourists and foreigners (García , 2020; Olivera, 2021). These measures may have had effects similar to those observed in Argentina, where, at a national level, the COVID-19 death rates were not higher in areas with lower socioeconomic conditions (Leveau, 2021). Overall, it is unclear to what extent neighborhood violence has also been a determinant of deaths from COVID-19 during the pandemic.

\subsection{Health and well-being in violent areas}

According to the World Health Organization (WHO), violence is not only a risk factor for the increased prevalence of communicable disease, it is also a global public health problem (WHO, 2002). Studies on how crime and violence affect the spread of diseases show different mechanisms. They can affect proximal causes of a disease: for example, by impeding vaccination (Guarino et al., 2017). Moreover,

Here, we refer to intentional homicides only, and exclude accidental homicides. 
high violence levels may block access to preventive health care, thus affecting disease transmission (Krystosik et al., 2018). Providing health care in dangerous areas with high urban violence may be challenging (Bellas et al., 2019). While the impact of violence on health is a global problem, it is especially concerning in low- and middle-income countries (Matzopoulos et al., 2008). In Mexico, violence - as measured by homicide rates - and poverty have been found to affect cardiometabolic risk biomarkers (Gaitán-Rossi, 2017): homicides impact fear of crime, and perceptions of risk and safety are amplified by poverty and inequality (Gaitan-Rossi and Shen, 2018). The indirect negative impact of crime and the fear of crime on health and well-being has also been observed in other contexts, according to a review of the theoretical and empirical literature (Lorenc et al., 2012). Whether this is also the case for the COVID-19 pandemic is still an open question.

\subsection{Crime and violence in Mexico: Before and during the pandemic}

The Mexican government implemented a strategy to reduce social mobility, limited to essential work, and promoted staying at home with a nonmandatory lockdown in March 2020 (DOF, 2020). Despite the apparent decline in reports of various crimes following the implementation of the stay-at-home measures, homicides increased in 2020. According to official data from the National Public Security System (SESNSP, in Spanish), the second-highest monthly number of intentional homicides in Mexico's recent history was recorded in March 2020, at 3,119 homicides. Postconfinement, the situation did not improve much: between March and December 2020, more than 3,000 homicides were registered over five months, and the average monthly number of homicides was 2,942 (SESNSP, 2021).

Many of these homicides were the result of armed clashes between organized crime groups fighting for territory control. Thus, criminal activity might reflect a lack of obedience to stay-at-home measures or of willingness to adhere to general public health guidance, as well as a different conception of the rule of law (International Crisis Group, 2020). The media has reported possible implications of COVID-19 for the large drug-related industry. Various criminal groups have seen the pandemic as an opportunity to continue creating and weaving their security and support networks around territories they control or are in dispute over. Diverse media outlets have documented how the Jalisco Nueva Generación, Sinaloa and Golfo cartels, as well as other criminal groups in northern and western Mexico, provided cash transfers, credits or groceries and basic goods to local populations (Grillo, 2020; International Crisis Group, 2020; Nájar, 2020a). These provisions occurred in the face of increasing unemployment, a reduction of income sources and lack of support from local and federal governments. In 2020, homicides and crime committed in private spaces - that is, the home and workplace-increased, especially against women, children and other vulnerable groups (Hoehn-Velasco et al., 2020). Despite an initial drop in the number of complaints registered at the 
beginning of confinement, crime increased in various regions and reached levels similar to or higher than those prior to 2020, according to SESNSP data and emergency call records to 911 (Balmori de la Miyar et al., 2021). It is unclear whether areas with high violence between gangs or criminal groups might indirectly promote stay-at-home decrees due to the perception of insecurity, thus reducing COVID-19 risk, or whether violence and this adverse environment discourage people from seeking testing for COVID-19 or going to a hospital if the disease becomes serious.

\subsection{The current study}

Few studies have analyzed the association between prior crime or violence and mortality due to COVID-19. Studies on the impact of the pandemic on crime during 2020 and beyond may suffer from reverse causality because crime may be positively associated with the incidence of COVID-19. To fill this gap in the literature, our overarching research question is: What is the association between criminal violence and robbery prior to the pandemic and current mortality due to COVID-19? Specifically, we ask: (1) What is the association of these two types of crime in the pre-pandemic year of 2019 with ASCDR due to COVID-19 in 2020 at the municipality level among urban municipalities in Mexico; and (2) does this association differ by sex? In other words, do different sources of crime show different associations with men's and women's COVID-19 mortality rates? This last question is relevant given the sex differences in the impact of violence and crime, in the incidence of the disease (Betron et al., 2020; Bwire, 2020) and in mortality more broadly.

\section{Data, measures and methods}

\subsection{Data}

We use publicly available data from the Mexican Secretariat of Health (DGE, 2021), with individual data for 192,797 deaths from COVID-19 as of December 31,2020 , published on July $31,2021 .^{2}$ From January 1 to December 31, 2020, the data show a cumulated total of 71,681 female deaths and 121,116 male deaths attributed to the COVID-19. The data include information on comorbidities as well as basic demographic characteristics, such as age, sex, place of birth, municipality of residence and municipality of testing. This database considers confirmed and suspicious deaths from COVID-19, with a regular lag period of approximately

\footnotetext{
2 These official, publicly available data are updated every day, and feed the COVerAGE-DB database, an open-access database that includes data from more than 108 countries (Riffe et al., 2021).
} 
15 to 20 days (DGE, 2021). According to official information from the Mexican Secretariat of Health, all suspicious deaths are tested for COVID-19 independently of age (DGE, 2021). ${ }^{3}$ Thus, we do not expect systematic age biases in COVID19 death undercounts, although our estimates on the severity of mortality due to COVID-19 are conservative. By using data published on July 31, 2021, we reduce biases associated with late registration; and by considering confirmed and suspicious deaths, we reduce differences in testing availability within the country. Until vital registration data are published in December 2021 by the National Institute of Statistics and Geography (INEGI), publicly available data from the Mexican Health Secretariat on deaths attributed to COVID-19 are the best-suited data for studying mortality. We are aware that no single data source is fully accurate in terms of incidence or fatalities (Riffe et al., 2021).

We aggregate data by municipality of residence to generate the total numbers of female and male deaths due to COVID-19 in 2020. ${ }^{4}$ Municipalities are the secondlevel administrative divisions of Mexico, and states are the first level. We calculate crude death rates by sex considering Mexican official population projections as of mid-2020 (CONAPO, 2018) ${ }^{5}$ as the quotient between the total number of male (female) deaths by municipality of residence for every 10,000 inhabitants of the projected male (female) population in the municipality as of mid-2020. We further calculate age-standardized crude death rates (ASCDR) by sex using the national age structure of the population projection for both sexes as of midyear 2020 following Preston and colleagues (2001). This standardization allows for comparisons by sex and municipalities. Of the 2,457 municipalities in the country, ${ }^{6} 2,416$ had female deaths and 2,420 had male deaths in 2020 . We narrow the bias in COVID-19 undertesting by restricting our analyses to deaths of residents of urban municipalities, but we expect that our results will be conservative for smaller and more isolated urban areas with limited transportation to large urban and metropolitan areas where hospitals and clinics are available. Once we restrict our sample to the 1,194 urban municipalities with a population of more than 15,000 , we consider 69,862 female deaths and 118,125 male deaths. Our working sample,

\footnotetext{
3 According to the Health Secretariat, Mexico has followed the guidelines established by the WHO, and underreporting of COVID-19 in Mexico has been decreasing over time (DGE, 2021).

4 The first case of death due to COVID-19 in Mexico recorded in the database dates to January 2, 2021.

5 The complete methodology of the population projections is available at the CONAPO website. These population projections have been created by a group of demographers, and constitute the official information used for national decision-making.

6 Mexico has 2,457 municipalities located in 32 states. More than 400 municipalities are located in the state of Oaxaca, and most of these municipalities are small rural areas governed by indigenous customary law. This fine division into small areas in the state reflects Oaxaca's greater rurality and isolation compared with other states.
} 
after we consider missing values in covariates and outliers, ${ }^{7}$ is 1,113 municipalities for studying female mortality (cumulated 69,749 deaths) and 1,150 municipalities for studying male mortality (cumulated 117,960 deaths). The data on deaths have fewer biases associated with test availability than the data on confirmed cases. The underestimation of confirmed number of COVID-19 cases has been documented in other contexts, such as in the United States, where rural-urban differences are partially attributable to underreporting (Souch and Cossman, 2020).

\subsection{Measures}

We study ASCDR of COVID-19 for men and women in urban municipalities, using the logarithm transformation to account for nonlinear relationships. Our two dependent variables are the natural logarithm of male and female ASCDR by municipality, based on the projected population by sex in 2020 (CONAPO, 2018). Our key independent variables-homicides and robberies-capture violence and crime prior to the COVID-19 pandemic. We consider the natural logarithm of the rate of criminal reports in 2019 by the projected population of the municipality by 2019 (per 10,000). Intentional homicides do not include deaths by accident or by negligence, while robberies are defined as crimes in which property is unlawfully taken in public and private spaces through the use of violence. Thus, a robbery (violent) should not be confused with a theft or burglary (nonviolent). These data are provided by the SESNSP and include cases reported to a public ministry for which an investigation file was opened (SESNSP, 2021). Although these data may present biases of underreporting, these are the most recent available data at the municipality level before the pandemic and the most widely used data to study crime in Mexico. Underreporting bias is expected to be larger in rural and smaller urban areas that are isolated or are located far from a public ministry office. Underreporting of robbery and homicides might also be more common in places with high crime rates. In other words, results will be conservative due to underestimation of crime rates.

We control for a series of independent variables at the municipality level prior to the onset of the pandemic that are known to influence mortality. We control for the old-age structure of the municipality using the natural logarithm of the aging index, calculated as the relationship between the elderly population aged 65 and older and children under age 15 according to the population projection as of mid2020. We control for the natural logarithm of population density defined as total population in the municipality per square kilometer. We include two independent variables for health conditions that are known to be associated with severe COVID19 cases in Mexico (Denova-Gutiérrez et al., 2020) and elsewhere: namely, the natural logarithm of the prevalence of obesity and diabetes in 2018, as estimated by the Ministry of Health using data from the 2018 Mexican National Health Survey

\footnotetext{
7 We omitted 16 municipalities with small population sizes that were considered outliers in terms of their homicide rates, robbery rates, obesity prevalence, Gini index, mean salary income and EAP.
} 
(ENSANUT) and small-area estimation procedures (INEGI, 2021). To capture geographic and social accessibility or isolation, we define a categorical variable using the 2020 Degree of Accessibility to a Paved Road ${ }^{8}$ provided by the Mexican Council for Evaluation of Social Development Policy (CONEVAL, 2021). At the municipality level, CONEVAL publishes the percentage of the population with very low or low access to a paved road. We define the quintile categorical variable to distinguish between very low, low, medium, high and very high (reference group) inaccessibility to a paved road. By controlling for access to a paved road, we take into account the potential underestimation bias of mortality associated with COVID-19 testing and reporting, but most importantly, we consider the isolation of communities, which may act protectively against the disease. ${ }^{9}$ We control for economic inequality within the municipality using the Gini index for 2015, also provided by CONEVAL. Finally, we use 2020 Mexican census data (INEGI, 2021) to define two economic variables. We consider the natural logarithm of the male and female economically active population (EAP) to take into account the workingage population by sex, and the natural logarithm of mean salary income for the population aged $15-64$ years. ${ }^{10}$

\subsection{Methods}

First, our descriptive analysis includes summary statistics of our dependent and independent variables (before transformations) in urban municipalities with female and male COVID-19 deaths, respectively, as well as correlation matrices. Second, we estimate a series of OLS regression models on the natural logarithm of male and female ASDCR. Each of the first two models include one of the crime indicators (homicides and robberies, respectively); the third model includes both indicators; the fourth model incorporates the aging index and the population density; the fifth model adds health conditions; and the sixth model is the fully adjusted model that adds socioeconomic variables as captured by inaccessibility, inequality, EAP and income. We also calculate the marginal effects of each variable in the fully adjusted models. To illustrate the associations between crime and mortality, we

\footnotetext{
8 This is one of the indicators used in multidimensional poverty included by law, and estimated by CONEVAL.

9 Preliminary analyses considered poverty instead of accessibility to a paved road as well as years of schooling. We prefer to use access to a paved road over poverty and other indicators due to the higher goodness of fit in the estimated models, and because it takes into account geographical and social connectivity. The most recent indicators of poverty at the municipality level published by CONEVAL, the agency that is responsible for publishing such indicators by law, are only multidimensional poverty indicators, and are available for 2015. Marginality (a widely used indicator in Mexico, calculated as an index similar to HDI) is available for 2015 and 2020 at the municipality level.

10 We decided to include the continuous variable for parsimony, but results are robust to the inclusion of mean salary income as continuous or categorical variables using deciles, as well as to the 2015 and 2020 marginality index, and the multidimensional poverty for 2015 .
} 
show graphs of the average estimated ASCDR at different levels of the logarithm of rates of reports of homicides and robberies. We perform heteroskedasticity and multicollinearity tests, and we use BIC and AIC indicators of goodness of fit.

\section{Results}

\subsection{Descriptive analysis}

Similar to other countries, the number of deaths due to COVID-19 in Mexico in 2020 was higher among men than among women. Table 1 shows summary statistics for selected characteristics for municipalities with female and male deaths displayed separately. Mean and median ASCDR due to COVID-19 are 45\% and $50 \%$ higher, respectively, for men than women. Overall, indicators do not differ much for municipalities with male or female deaths. Urban municipalities with female deaths have similar but slightly higher average rates of intentional homicides and robbery than urban municipalities with male deaths (2.09 and 2.08 homicides per 10,000; and 32.57 and 31.7357 robberies per 10,000, respectively). The average aging index is $31 \%$ of adults aged 65 years and older for every child younger than 15. Female labor force participation in Mexico is low: the mean percentage of female EAP is $45.2 \%$ compared with an average male EAP of $77.0 \%$. In urban municipalities with deaths due to COVID-19, approximately $9 \%$ of the population, on average, has low accessibility to paved roads. The median Gini index is 39.9 for both types of municipalities. In terms of health conditions, the average prevalence of obesity at the municipality level is more than 1 in 3; and of diabetes, more than 1 in 10. As we noted previously, these two comorbidities are important risk factors for mortality associated with COVID-19. Finally, the average salary income at the municipality-level is over 6,000 pesos per month (approximately US \$300).

In Mexican urban municipalities, homicide rates and robbery rates are negatively correlated with the Gini index even if this correlation is small (see Table 2). As expected, homicide and robbery rates are positively correlated in both types of urban municipalities. Although the correlations of variables used in the model could be considered low, a couple of them are above 0.5 and worth noting. First, the correlation of the aging index with diabetes is as expected. Second, the female EAP and the robbery rate in municipalities with female deaths reflect greater female labor force participation in larger and more-affluent urban areas. For future reference, Appendix A shows scatterplots for these variables (see Figures A.1 and A.2).

\subsection{Results: OLS regression models}

Table 3 shows the results from a series of OLS regression models on the natural logarithm of female and male age-standardized crude death rates (ASCDR) due to COVID-19 of urban municipalities in Mexico. In the unadjusted models that 


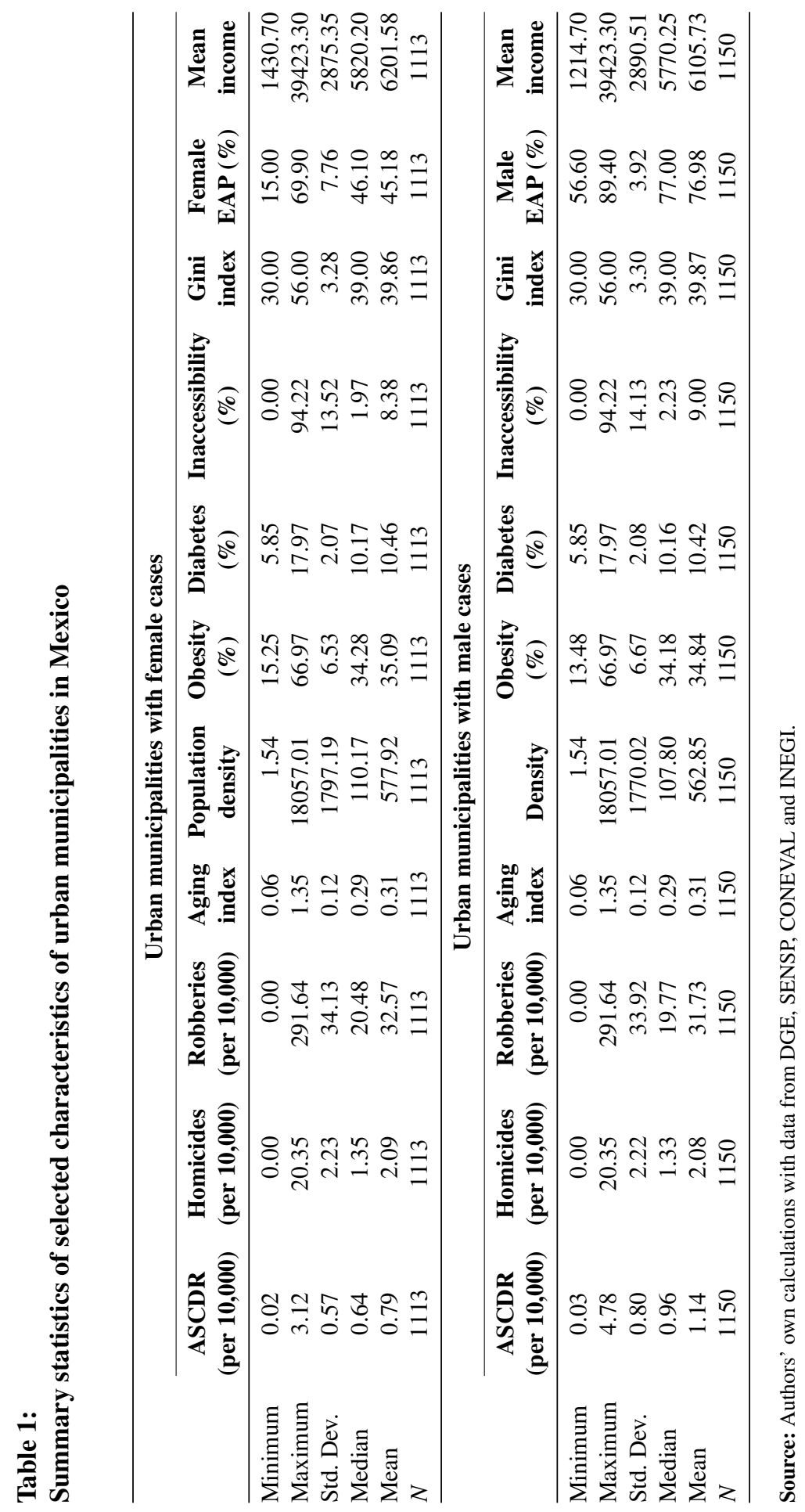




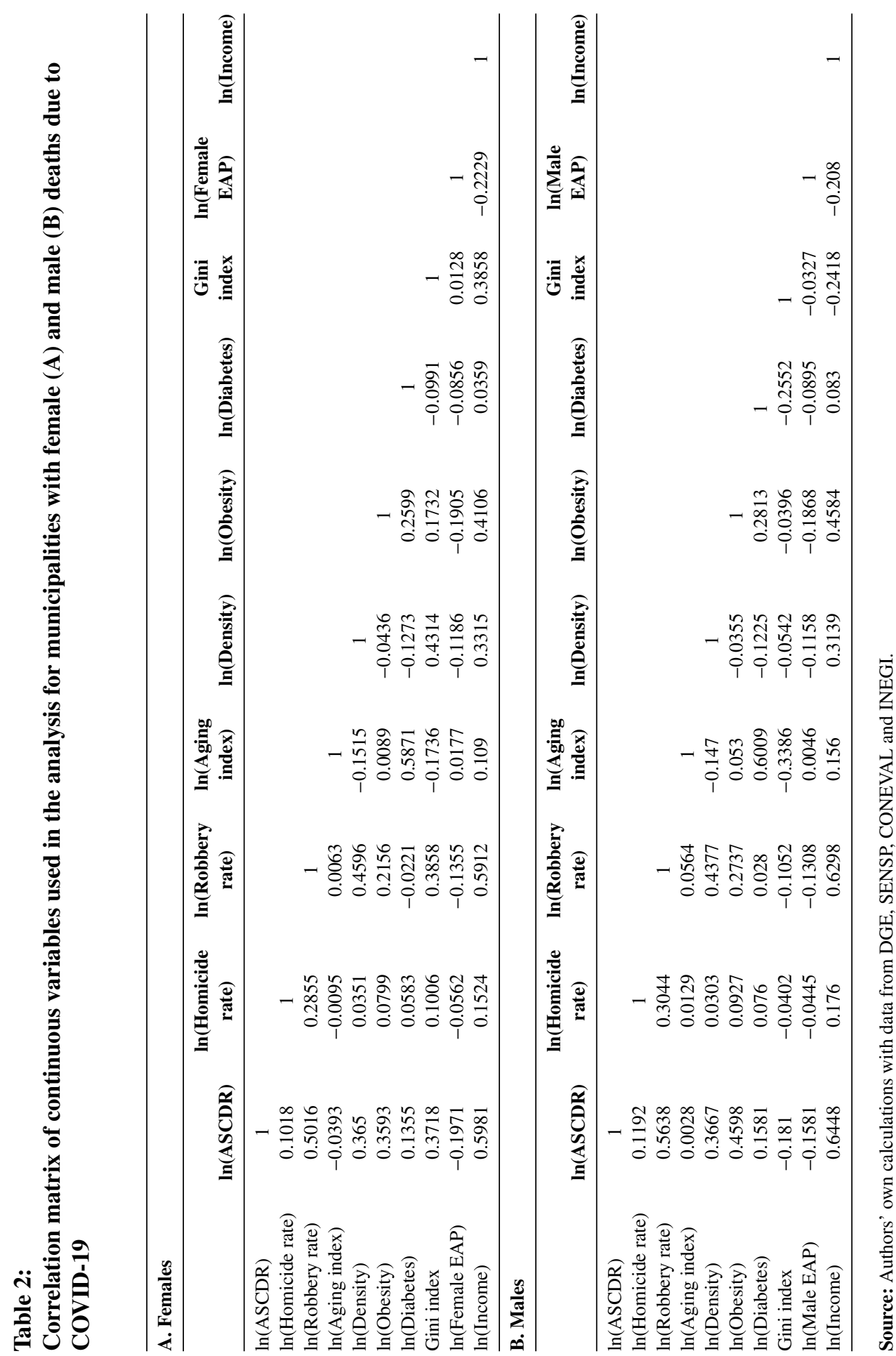




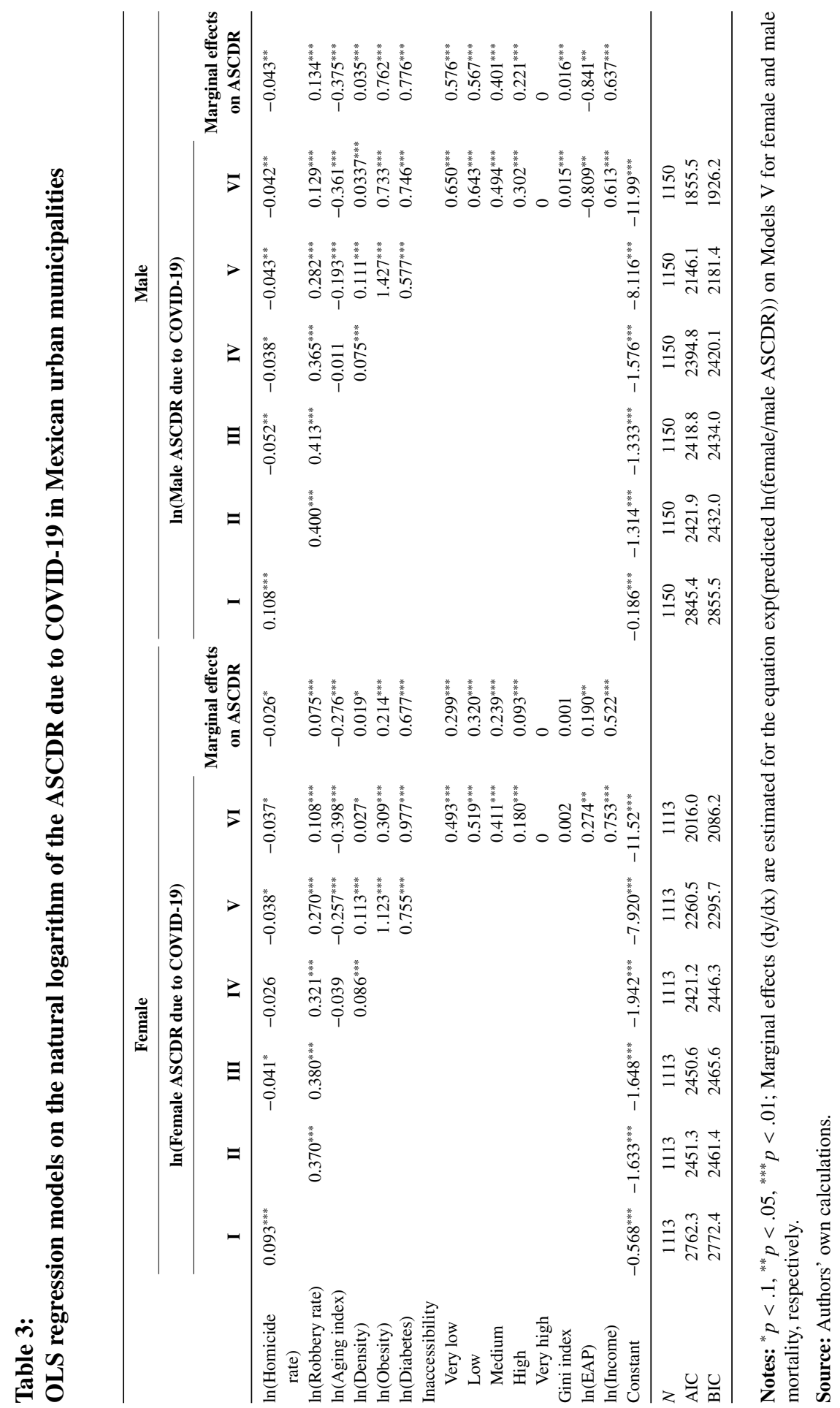


include them one at a time (I and II), 2019 crime rates are positively associated with ASCDR in 2020. The direction of the association between homicide rates and mortality changes after we control for aging and population density for men (Model IV). Fully adjusted models (VI) show a negative significant association $(p<.1)$ between intentional homicide rates and female and male ASCDR, and a positive association $(p<.001)$ between robbery rates and ASCDR for both sexes. In other words, homicides (a proxy for criminal violence) and robbery (a proxy for safety concerns) in the pre-pandemic year of 2019 have different associations with ASCDR due to mortality in 2020. In both cases, the marginal effects of crime rates are larger for male mortality than for female mortality.

Figure 1 illustrates these associations with graphs of average estimated female (panel A) and male (panel B) ASCDR at different levels of the logarithm of rates of reports of homicides and robbery (from Models VI by sex). The graphs clearly show that urban municipalities that had higher robbery rates tended to have higher mortality due to COVID-19, and that this association is stronger for men than for women.

Estimated associations of ASCDR and other indicators show interesting differences by sex that can help explain the role of the social determinants of mortality due to COVID-19 for men and women. It is worth noting that the association of the EAP differed between men and women. A higher percentage of female EAP is associated with an increase in the logarithm of mortality due to COVID-19 among women, whereas male EAP is negatively associated with mortality. In other words, although female labor force participation generally empowers women in Mexico, during the pandemic, women were more exposed than men to economic activities with greater risk of contagion and mortality. Another related explanation is that female labor force participation is associated with other socioeconomic characteristics that put women at risk. For the rest of the indicators, results show similar associations and marginal effects for male and female ASCDR. The prevalence of obesity and diabetes put men and women at risk of death, although the risk is much larger for men. By contrast, isolation and less access to a paved road protects communities from contagion and death. The negative association between aging in the municipality and ASCDR suggests that in the context of the pandemic, older adults were made aware of their vulnerability to COVID-19, and thus avoided contagion by staying home. Interestingly, mean salary income was positively associated with ASCDR, and the larger marginal effects for male ASCDR and the positive and significant association with the Gini index reflect different processes linking economic characteristics and male mortality.

\section{Discussion}

Findings from OLS regression models show that the pre-pandemic intentional homicide rates have a significant negative association with ASCDR due to COVID19 for both men and women, whereas the robbery rate is positively associated with 
Figure 1:

Average estimated female (A) and male (B) ASCDR due to COVID-19 at levels of homicide and robbery rates in urban municipalities in Mexico

A. Females
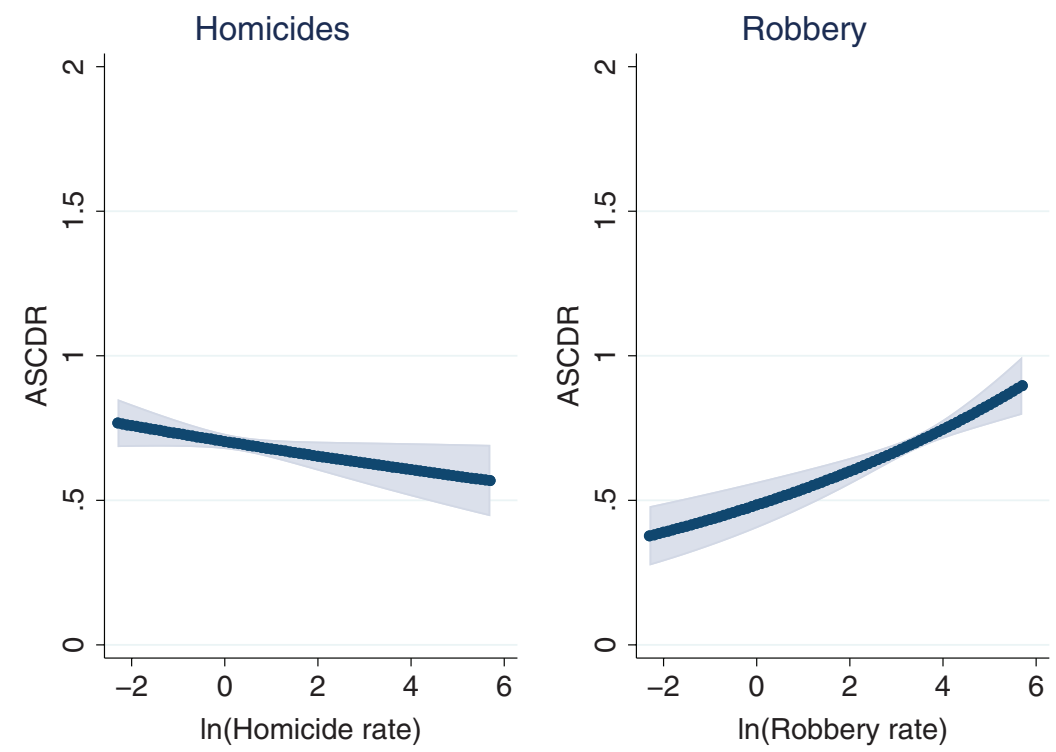

B. Males
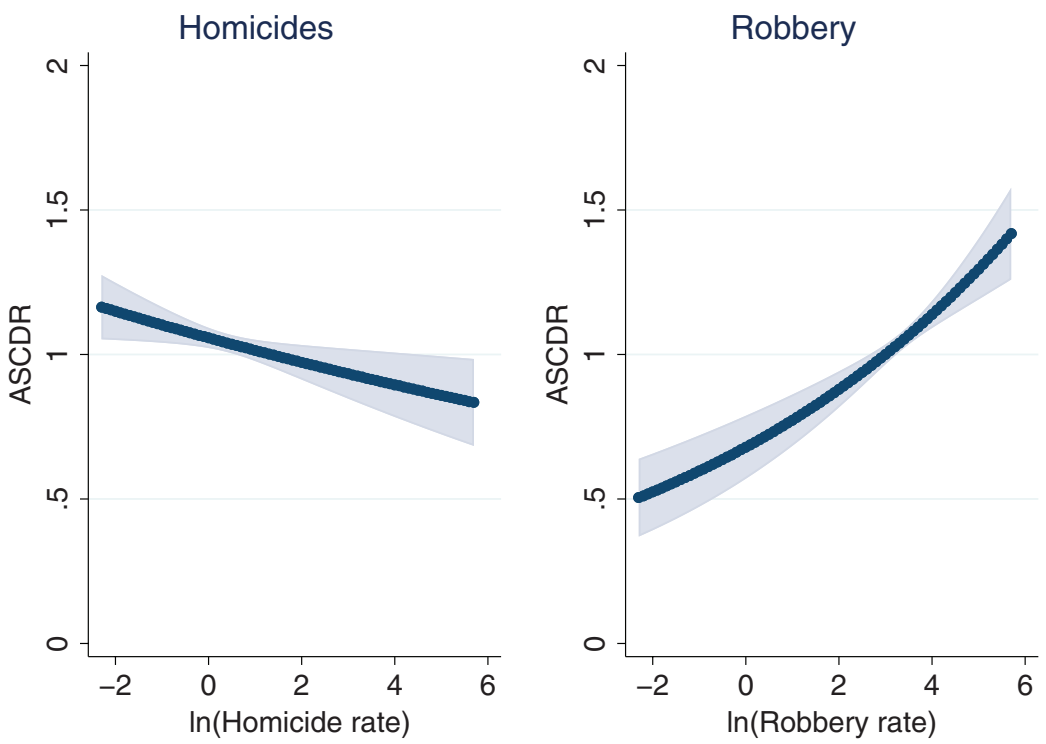

Source: Authors' own calculations from predictions for Models V for female and male mortality, respectively, Table 3. 
ASCDR due to COVID-19. These findings suggest that violence and crime affect mortality differently depending on whether these events happen in private or public spaces, but also on their severity and nature, reflecting more profound differences in contexts and social environments. Robberies prior to the COVID-19 pandemic affected mortality during the pandemic. Our findings suggest the need to better understand the role of violence in local contexts before and after the outbreak of the disease. Our results also suggest the need to consider differently the nature of violence as well as its implications for health protective measures for men and women.

We need to be cautious when stating that a climate of criminal violence protected the population from dying of COVID-19. Although homicides themselves may reduce the likelihood of venturing out if leaving home is risky-similar to what has been found in places with high urban violence and conflict for other diseases (Krystosik et al., 2018) — areas controlled by drug cartels might limit access to health authorities, and fewer medical personnel may have been sent to these risky areas by federal and state governments. Although we use death data published by the end of July 2021, which allowed enough time for deaths from COVID19 to be registered in the publicly available database, the uncertain reliability of the data from municipalities with very high crime rates controlled by drug cartels could be affecting our results. In addition, the people living in municipalities with high levels of violence were more likely to be internally displaced and may have left these violent areas during 2020 in search of protection and safety (Rodríguez Chávez, 2021; 2022). It is also possible that criminal groups operated differently during the pandemic, which led to reductions in the risk of contagion, and, in turn, to reductions in mortality due to COVID-19. For example, in China, the COVID-19 pandemic affected the production of synthetic drugs, such as fentanyl and methamphetamines, which have displaced marijuana, cocaine, and heroin in the United States, generating millions of dollars for Mexican cartels and their Chinese allies (Nájar, 2020b; Pastor, 2020). The pandemic caused a shortage in supplies of synthetic drug precursors, and cartels had to seek new sources of supplies and implement new production processes (UNODC, 2020). Lockdown measures and strengthened U.S. border controls made it difficult for drugs to reach consumers during 2020, thus reducing traditional drug-trafficking routes, increasing costs and risks and making drug sales in public places more difficult. All of these factors led to increases in online drug sales that were made through the so-called darknet, and were delivered by mail or parcel post (Pastor, 2020; UNODC, 2020). Whether these changes in how cartels operated during 2020 translated into a more favorable context is uncertain.

The consistent increase in homicide rates and in diabetes prevalence have contributed greatly to the reductions in life expectancy in Mexico (Canudas-Romo et al., 2015). More recently, using the same data as we do (DGE, 2021), a study that examined the negative impact of the COVID-19 pandemic on Mexican life expectancy estimated that in 2020, life expectancy at birth declined 2.5 years for 
females and 3.6 years for males, although these losses varied by state, with the effects of the COVID-19 pandemic being smaller in poorer states (García-Guerrero and Beltrán, 2021). Comparing the impact of violence and the impact of COVID19 on life expectancy in Mexico is beyond the scope of this paper. Time will tell whether the effects of the pandemic are larger or smaller than the effects of drugrelated violence. In absolute terms, from January 1, 2020 to December 31, 2020, the number of deaths attributed to COVID-19 $(192,797)$ was more than five times as high the number of homicides recorded $(35,531)$. However, a better understanding of the interrelationship of these global health problems, and of the contextual factors that put population health at risk, is still needed.

What we know about COVID-19 in Mexico-and globally—is highly influenced by government strategies for managing the pandemic, from testing and the implementation of lockdown measures, to providing economic support to businesses and economic resources to the health sector. Other social processes also influence our data. For example, of particular interest in the context of our research questions are the potential gender differences associated with access to preventive health, knowledge of comorbidities, COVID-19 testing and perceptions of risk factors, which, in turn, may have affected the confirmation rates and the data on the incidence of COVID-19. All these processes might be influenced themselves by neighborhood effects and local violence and insecurity. Moreover, although we focus on urban municipalities, future research should study conditions in rural areas in order to better understand the severity of the pandemic in smaller municipalities. Such research should be possible after vital official statistics for 2020 are published. Including these areas would, for example, make it possible to perform multivariate spatial analysis, although caution is advised given the biases and other processes associated with differences in how indicators of independent variables are reported in rural and urban areas. For example, if we are interested in studying how past forms of other types of crimes, such as domestic violence, are related to current COVID-19 incidence or mortality, it would be important to take into account biases in underreporting, not only due differences in the likelihood of filing a report, but also because gender roles shape who considers this crime worth reporting. We hope that our study opens new venues of research on the complex relationship between COVID-19 and its contextual determinants.

\section{Acknowledgements}

We are grateful for the Mexican funding agency that indirectly supported our research. Claudia Masferrer is a member of the National Researchers System (SNI, from its acronym in Spanish) of Consejo Nacional de Ciencia y Teconología (CONACYT), and El Colegio de la Frontera Norte receives funding from CONACYT. We appreciate comments we received from Víctor Manuel García-Guerrero and three anonymous reviewers that improved our analysis. 


\section{Availability of data and code}

Data are available at https://www.gob.mx/salud/documentos/datos-abiertos-152127, and the code is available upon request.

\section{ORCID}

Claudia Masferrer (1) https://orcid.org/0000-0002-0902-7723

Oscar Rodríguez Chávez ${ }^{(0)}$ https://orcid.org/0000-0002-7255-0605

\section{References}

Abrams, D. S. (2021). COVID and crime: An early empirical look. Journal of Public Economics, 194, Article 104344. https://doi.org/10.1016/j.jpubeco.2020.104344

Arteaga-Botello, N., Dávila-Cervantes, C. A., and Pardo-Montaño, A. M. (2019). Necrospaces and violent homicides in Mexico. International Journal of Conflict and Violence (IJCV), 13. https://doi.org/10.4119/UNIBI/ijcv.660

Balmori de la Miyar, J. R., Hoehn-Velasco, L., and Silverio-Murillo, A. (2021). Druglords don't stay at home: COVID-19 pandemic and crime patterns in Mexico city. Journal of Criminal Justice, 72, Article 101745. https://doi.org/10.1016/j.jcrimjus.2020.101745

Barquera, S., Hernández-Barrera, L., Trejo-Valdivia, B., Shamah, T., Campos-Nonato, I., and Rivera-Dommarco, J. (2020). Obesidad en México, prevalencia y tendencias en adultos. Ensanut 2018-19. Salud Pública de México, 62(6), 682-692. https://doi.org/10.21149/ 11630

Bellas, H. C., Jatobá, A., Bulhões, B., Koster, I., Arcuri, R., Burns, C., ... de Carvalho, P. V. R. (2019). Effects of urban violence on primary healthcare: The challenges of community health workers in performing house calls in dangerous areas. Journal of Community Health, 44(3), 569-576. https://doi.org/10.1007/s10900-019-00657-2

Bello-Chavolla, O. Y., Bahena-López, J. P., Antonio-Villa, N. E., Vargas-Vázquez, A., González-Díaz, A., Márquez-Salinas, A., ... Aguilar-Salinas, C. A. (2020). Predicting mortality due to SARS-CoV-2: A mechanistic score relating obesity and diabetes to COVID-19 outcomes in Mexico. The Journal of Clinical Endocrinology and Metabolism, 105(8), 2752-2761. https://doi.org/10.1210/clinem/dgaa346

Betron, M., Gottert, A., Pulerwitz, J., Shattuck, D., and Stevanovic-Fenn, N. (2020). Men and COVID-19: Adding a gender lens. Global Public Health, 15(7), 1090-1092.

Boman, J. H., and Gallupe, O. (2020). Has COVID-19 changed crime? Crime rates in the United States during the pandemic. American Journal of Criminal Justice, 45(4), 537-545. https://doi.org/10.1007/s12103-020-09551-3

Bwire, G. M. (2020). Coronavirus: Why men are more vulnerable to COVID-19 than women? SN Comprehensive Clinical Medicine, 2, 874-876. https://doi.org/10.1007/s42399-02000341-w 
Canudas-Romo, V., García-Guerrero, V. M., and Echarri-Cánovas, C. J. (2015). The stagnation of the Mexican male life expectancy in the first decade of the 21st century: The impact of homicides and diabetes mellitus. Journal Epidemiology and Community Health, 69(1), 28-34. https://doi.org/10.1136/jech-2014-204237

CONAPO. (2018). Proyecciones de la población en México y sus entidades federativas 2016-2050. CONAPO-UNFPA https://www.gob.mx/conapo/acciones-y-programas/ conciliacion-demografica-de-mexico-1950-2015-y-proyecciones-de-la-poblacion-demexico-y-de-las-entidades-federativas-2016-2050

CONEVAL. (2020). Hallazgos - Junio 2020. Visor Geoespacial de la Pobreza y la COVID-19 en los municipios de México. Retrieved from https://www.coneval.org.mx/MEDICION/ MP/PAGINAS/HALLAZGOS_JUNIO.ASPX

CONEVAL. (2021). Consejo Nacional de Evaluación de la Política de Desarrollo Social. https://www.coneval.org.mx

Denova-Gutiérrez, E., Lopez-Gatell, H., Alomia-Zegarra, J. L., López-Ridaura, R., ZaragozaJimenez, C. A., Dyer-Leal, D. D., .. B Barquera, S. (2020). The association of obesity, type 2 diabetes, and hypertension with severe coronavirus disease 2019 on admission among Mexican patients. Obesity, 28(10), 1826-1832. https://doi.org/10.1002/oby.22946

DGE. (2021). Datos Abiertos, Dirección General de Epidemiología. Retrieved from https: //www.gob.mx/salud/documentos/datos-abiertos-152127

Diez Roux, A. V. (2020). Population health in the time of COVID-19: Confirmations and revelations. The Milbank Quarterly, 98(3), 629-640. https://doi.org/10.1111/1468-0009. 12474

DOF. (2020). ACUERDO por el que se establecen las medidas preventivas que se deberán implementar para la mitigación y control de los riesgos para la salud que implica la enfermedad por el virus SARS-CoV2 (COVID-19). Mexico. https://www.dof.gob.mx/nota_ detalle.php?codigo $=5590339 \&$ fecha $=24 / 03 / 2020$

Ejaz, H., Alsrhani, A., Zafar, A., Javed, H., Junaid, K., Abdalla, A. E., ... Younas, S. (2020). COVID-19 and comorbidities: Deleterious impact on infected patients. Journal of Infection and Public Health, 13(12), 1833-1839. https://doi.org/10.1016/j.jiph.2020.07. 014

El Colegio de México. (2018). Desigualdades en México 2018. Red de Estudios sobre Desigualdades, El Colegio de México. Mexico City, Mexico. https:/desigualdades.colmex. $\mathrm{mx} /$ informe-desigualdades-2018.pdf

Ellen, I. G., Mijanovich, T., and Dillman, K.-N. (2001). Neighborhood effects on health: Exploring the links and assessing the evidence. Journal of Urban Affairs, 23(3-4), 391408. https://doi.org/10.1111/0735-2166.00096

Gaitán-Rossi, P. (2017). The contextual effects of violence and poverty on cardiometabolic risk biomarkers: A longitudinal multilevel study in urban municipalities in Mexico. Boston College. Retrieved from http://hdl.handle.net/2345/bc-ir:107649

Gaitán-Rossi, P., and Shen, C. (2018). Fear of crime in Mexico: The impacts of municipality characteristics. Social Indicators Research, 135(1), 373-399. https://doi.org/10.1007/ s11205-016-1488-x 
García, J. (2020). Los indígenas de México se cierran para frenar al coronavirus. El Pais. https://elpais.com/sociedad/2020-04-21/los-indigenas-de-mexico-se-cierran-parafrenar-al-coronavirus.html

García-Guerrero, V. M., and Beltrán, H. (2021). Heterogeneity in excess of mortality and its impact on loss of life expectancy due to COVID-19: Evidence from Mexico. Canadian Studies in Population, 48, 165-200. https://doi.org/10.1007/s42650-021-00051-1

Grillo, I. (2020). How Mexico's drug cartels are profiting from the pandemic. The New York Times, Retrieved from 7 July 2020, from https://www.nytimes.com/2020/07/07/opinion/ sunday/mexico-drug-cartels-coronavirus.html

Guarino, K., Voorman, A., Gasteen, M., Stewart, D., and Wenger, J. (2017). Violence, insecurity, and the risk of polio: A systematic analysis. PloS ONE, 12(10). https://doi.org/ 10.1371/journal.pone.0185577

Hodgkinson, T., and Andresen, M. A. (2020). Show me a man or a woman alone and I'll show you a saint: Changes in the frequency of criminal incidents during the COVID19 pandemic. Journal of Criminal Justice, 69, Article 101706. https://doi.org/10.1016/j. jcrimjus.2020.101706

Hoehn-Velasco, L., Silverio-Murillo, A., and Balmori de la Miyar, J. R. (2020). The great crime recovery: COVID-19 and crimes against women during, and after, the COVID-19 lockdown in Mexico. Economics $\mathcal{E}$ Human Biology, 41, Article 100991. https://doi.org/ 10.1016/j.ehb.2021.100991

IGG-UNAM. (2020). Visualizador de datos geográficos del iCOVID-19. Retrieved from https://www.gits.igg.unam.mx/iCOVID-19/home

INEGI. (2021). Prevalencia de obesidad, hipertensión y diabetes para los municipios de México 2018. Retrieved from https://inegi.org.mx/investigacion/pohd/2018/\#Tabulados

INEGI (2021). Censo de Población y Vivienda 2020. Retrieved from https://www.inegi.org. $\mathrm{mx} /$ programas/ccpv/2020/default.html\#Tabulados

International Crisis Group. (2020). Virus-proof violence: Crime and COVID-19 in Mexico and the Northern Triangle. Retrieved from https://www.crisisgroup.org/latin-americacaribbean/83-virus-proof-violence-crime-and-covid-19-mexico-and-northern-triangle

Krystosik, A. R., Curtis, A., LaBeaud, A. D., Dávalos, D. M., Pacheco, R., Buritica, P., .. . James, M. A. (2018). Neighborhood violence impacts disease control and surveillance: Case study of Cali, Colombia from 2014 to 2016. International Journal of Environmental Research and Public Health, 15(10), 2144. https://doi.org/10.3390/ijerph15102144

Kulu, H., and Dorey, P. (2021). Infection rates from Covid-19 in great Britain by geographical units: A model-based estimation from mortality data. Health $\mathcal{E}$ Place, 67, Article 102460. https://doi.org/10.1016/j.healthplace.2020.102460

Leveau, C. M. (2021). Difusión espacio-temporal de muertes por COVID-19 en Argentina. Revista Panamericana de Salud Pública, 45(3). https://doi.org/10.26633/RPSP.2021.3.

Lorenc, T., Clayton, S., Neary, D., Whitehead, M., Petticrew, M., Thomson, H., ... Renton, A. (2012). Crime, fear of crime, environment, and mental health and wellbeing: Mapping review of theories and causal pathways. Health $\mathcal{E}$ Place, 18(4), 757-765. https://doi.org/ 10.1016/j.healthplace.2012.04.001

Lozano, P., Fleischer, N. L., Moore, S., Shigematsu, L. M. R., Santillán, E. A., and Thrasher, J. F. (2016). Does neighborhood social cohesion modify the relationship between 
neighborhood social norms and smoking behaviors in Mexico? Health $\mathcal{F}$ Place, 40, 145152. https://doi.org/10.1016/j.healthplace.2016.05.011

Matzopoulos, R., Bowman, B., Butchart, A., and Mercy, J. A. (2008). The impact of violence on health in low- to middle-income countries. International Journal of Injury Control and Safety Promotion, 15(4), 177-187. https://doi.org/10.1080/17457300802396487

Mena, G. E., Martinez, P. P., Mahmud, A. S., Marquet, P. A., Buckee, C. O., and Santillana, M. (2021). Socioeconomic status determines COVID-19 incidence and related mortality in Santiago, Chile. Science, 372(6545), Article eabg5298. https://doi.org/10.1126/science. $\operatorname{abg} 5298$

Mitra, R., Moore, S. A., Gillespie, M., Faulkner, G., Vanderloo, L. M., Chulak-Bozzer, T., ldots Tremblay, M. S. (2020). Healthy movement behaviours in children and youth during the COVID-19 pandemic: Exploring the role of the neighbourhood environment. Health $\mathcal{E}$ Place, 65, Article 102418. https://doi.org/10.1016/j.healthplace.2020.102418

Mohler, G., Bertozzi, A. L., Carter, J., Short, M. B., Sledge, D., Tita, G. E., . . Brantingham, P. J. (2020). Impact of social distancing during COVID-19 pandemic on crime in Los Angeles and Indianapolis. Journal of Criminal Justice, 68, Article 101692. https://doi.org/ 10.1016/j.jcrimjus.2020.101692

Moreno-Altamirano, L., García-García, J. J., Soto-Estrada, G., Capraro, S., and Limón-Cruz, D. (2014). Epidemiología y determinantes sociales asociados a la obesidad y la diabetes tipo 2 en México. Revista Médica del Hospital General de México, 77(3), 114-123. https://doi.org/10.1016/j.hgmx.2014.07.002

Morenoff, Jeffrey D. (2003). Neighborhood mechanisms and the spatial dynamics of birth weight. American Journal of Sociology, 108(5), 976-1017. https://doi.org/10.1086/374405

Nájar, A. (2020a). Coronavirus en México: La paradoja de que el país registre el mayor número de homicidios del año en medio de la cuarentena. BBC News Mundo, México, 23 April 2020. https://www.bbc.com/mundo/noticias-america-latina-52406595

Nájar, A. (2020b). Fentanilo. Cómo operan los cárteles de México y China para vender esta potente droga en Estados Unidos. BBC News Mundo, 4 February 2020. https://www.bbc. com/mundo/noticias-america-latina-51117195

Nandi, A., and Kawachi, I. (2011). Neighborhood effects on mortality. In R. G. Rogers and E. M. Crimmins (Eds.), International handbook of adult mortality (pp. 413-439). Springer Netherlands. https://doi.org/10.1007/978-90-481-9996-9_20

Olivera, A. (2021). Fortalecen pueblos de la Sierra Norte prevención ante la Covid 19. Quadratin Oaxaca. https://oaxaca.quadratin.com.mx/fortalecen-pueblos-de-la-sierranorte-prevencion-ante-la-covid-19/

Pastor, M. (2020). El Coronavirus golpea las finanzas de los cárteles mexicanos. Documento informativo. 15 April 2020 http://www.ieee.es/Galerias/fichero/docs_informativos/2020/ DIEEEI15_2020LUIPAS_COVIDMexico.pdf

Payne, J. L., and Morgan, A. (2020). COVID-19 and Violent Crime: A comparison of recorded offence rates and dynamic forecasts (ARIMA) for March 2020 in Queensland, Australia. https://EconPapers.repec.org/RePEc:osf:socarx:g4kh7

Peña, J. E.-d. 1., Rascón-Pacheco, R. A., Ascencio-Montiel, I. d. J., González-Figueroa, E., Fernández-Gárate, J. E., Medina-Gómez, O. S., .. Borja-Aburto, V. H. (2021). 
Hypertension, diabetes and obesity, major risk factors for death in patients with COVID19 in Mexico. Archives of Medical Research, 52(4), 443-449. https://doi.org/10.1016/j. arcmed.2020.12.002

Pérez-Ferrer, C., Auchincloss, A. H., Barrientos-Gutierrez, T., Colchero, M. A., de Oliveira Cardoso, L., de Menezes, M. C., and Bilal, U. (2020). Longitudinal changes in the retail food environment in Mexico and their association with diabetes. Health and Place, 66, Article 102461. https://doi.org/10.1016/j.healthplace.2020.102461

Preston, S., Heuveline, P., and Guillot, M. (2001). Demography: Measuring and modeling population processes. Blackwell Publishers.

Riffe, T., Acosta, E., and COVerAGE-DB team. (2021). Data resource profile: COVerAGEDB: A global demographic database of COVID-19 cases and deaths. International Journal of Epidemiology, 50(2), 390-390f. https://doi.org/10.1093/ije/dyab027

Rivera, J. A., Pedraza, L. S., Martorell, R., and Gil, A. (2014). Introduction to the double burden of undernutrition and excess weight in Latin America. The American Journal of Clinical Nutrition, 100(6), 1613S-1616S. https://doi.org/10.3945/ajcn.114.084806

Rodríguez Chávez, O. (2021). Efectos de la violencia sobre las tasas de emigración interna municipal en México: 1995-2015. Migraciones Internacionales, 12. https://doi.org/10. 33679/rmi.v1i1.2045

Rodríguez Chávez, O. (2022). ¿De dónde salieron ya dónde se fueron? Migración interna de regiones de alta violencia en México en las últimas dos décadas. Revista EURE-Revista de Estudios Urbano Regionales, 48(144). https://doi.org/10.7764/EURE.48.144.12

Rodriguez-Diaz, C. E., Guilamo-Ramos, V., Mena, L., Hall, E., Honermann, B., Crowley, J. S., ... Millett, G. A. (2020). Risk for COVID-19 infection and death among Latinos in the United States: Examining heterogeneity in transmission dynamics. Annals of Epidemiology, 52, 46-53.e42. https://doi.org/10.1016/j.annepidem.2020.07.007

SESNSP. (2021). Criminal incidence data of the common jurisdiction at the municipality level. Retrieved 15 August 2021, from https://www.gob.mx/sesnsp/acciones-y-programas/ incidencia-delictiva-87005? idiom $=\mathrm{es}$

Souch, J. M., and Cossman, J. S. (2020). A commentary on rural-urban disparities in COVID19 testing rates per 100,000 and risk factors. The Journal of Rural Health, 37(1), 188-190. https://doi.org/10.1111/jrh.12450

Sy, K. T. L., Martinez, M. E., Rader, B., and White, L. F. (2021). Socioeconomic disparities in subway use and COVID-19 outcomes in New York city. American Journal of Epidemiology, 190(7), 1234-1242. https://doi.org/10.1093/aje/kwaa277

Tsai, A. C., Mendenhall, E., Trostle, J. A., and Kawachi, I. (2017). Co-occurring epidemics, syndemics, and population health. The Lancet, 389(10072), 978-982. https://doi.org/10. 1016/S0140-6736(17)30403-8

UNODC. (2020). Reseña de investigación: COVID-19 y la cadena de suministro de drogas: de la producción y el tráfico al consumo. Vienna: Oficina de las Naciones Unidas Contra la Droga y el Delito. https://www.unodc.org/documents/data-and-analysis/covid/Covid19_Suministro_de_Drogas.pdf

Wasdani, K. P., and Prasad, A. (2020). The impossibility of social distancing among the urban poor: The case of an Indian slum in the times of COVID-19. Local Environment, 25(5), 414-418. https://doi.org/10.1080/13549839.2020.1754375 
WHO. (2002). World report on violence and health. 2002. World Health Organization.

WHO. (2021). Transmission of SARS-CoV-2: Implications for infection prevention precautions. https://www.who.int/news-room/commentaries/detail/transmission-of-sarscov-2-implications-for-infection-prevention-precautions

Yang, Y., and Xiang, X. (2021). Examining the associations between perceived neighborhood conditions, physical activity, and mental health during the COVID-19 pandemic. Health $\mathcal{E}$ Place, 67, Article 102505. https://doi.org/10.1016/j.healthplace.2021.102505

\section{Appendix A: Scatterplot graphs of continuous variables used in the analysis for municipalities with female (A.1) and male (A.2) deaths due to COVID-19}

Figure A.1:

Females

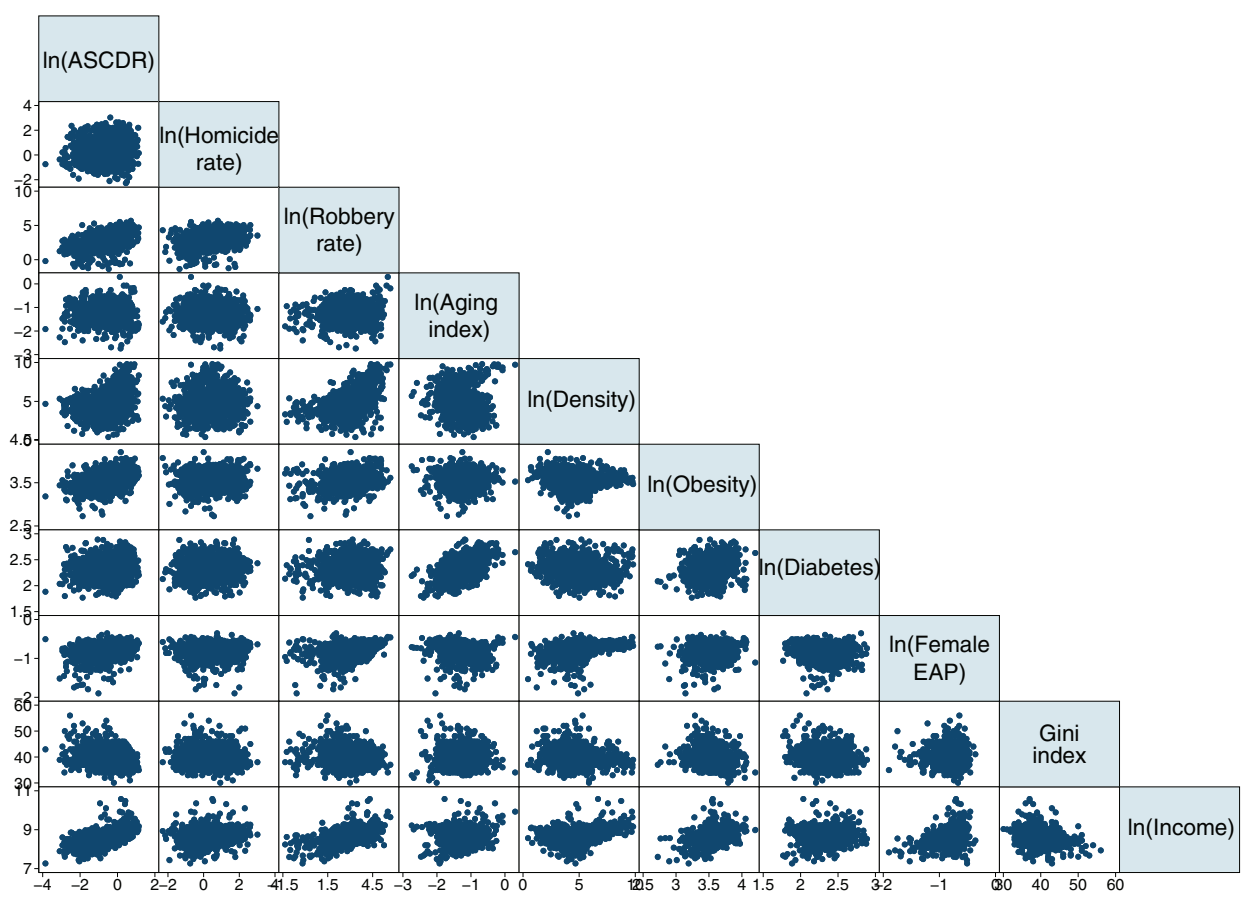


Figure A.2:

Males

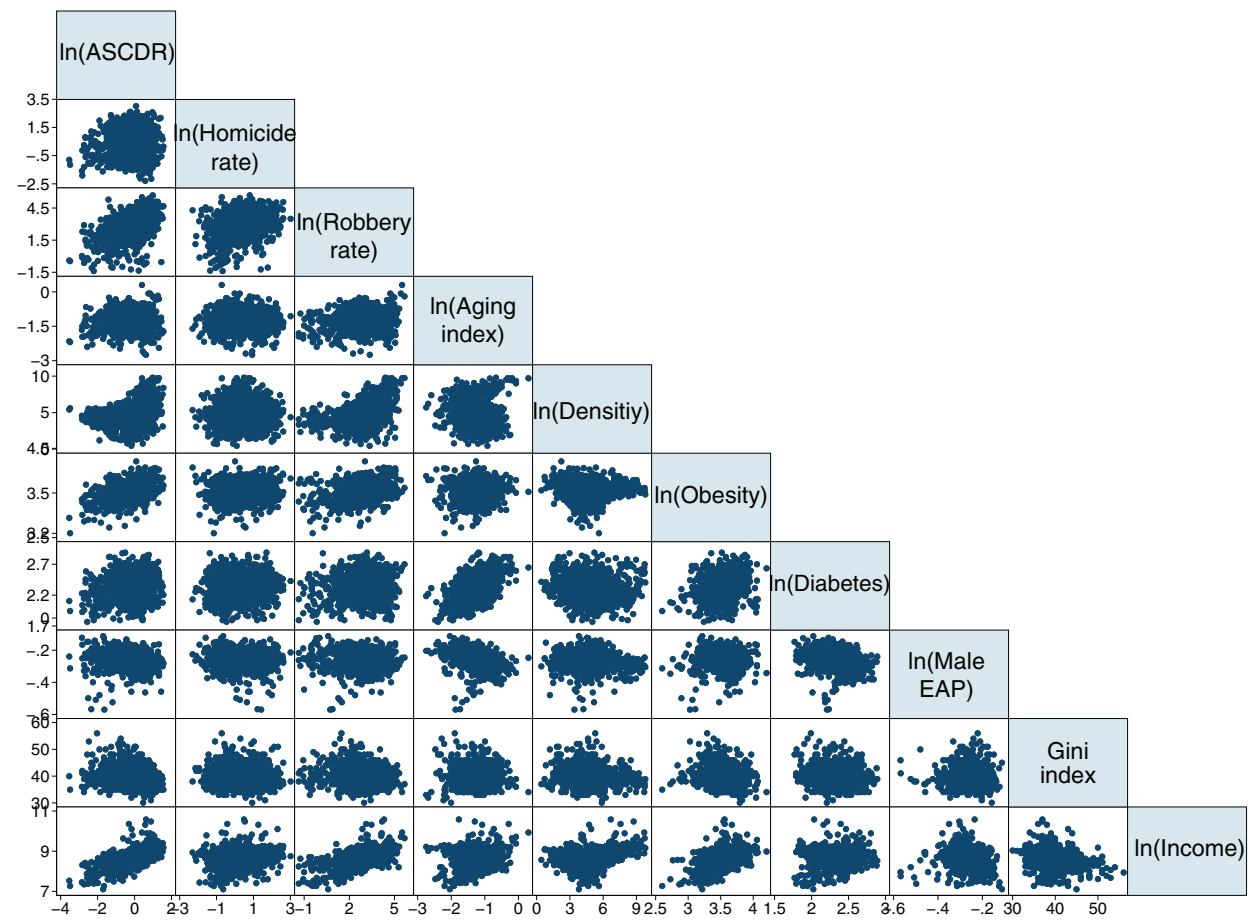

Open Access This article is published under the terms of the Creative Commons Attribution 4.0 International License (https://creativecommons.org/licenses/by/4.0/) that allows the sharing, use and adaptation in any medium, provided that the user gives appropriate credit, provides a link to the license, and indicates if changes were made. 